\title{
SEASONAL VARIATION IN ROOTING BEHAVIOUR OF GINKGO BILOBA L. CUTTINGS
}

\author{
N. Bhattarai ${ }^{1}$ and S.D. Joshi ${ }^{2}$
}

\section{ABSTRACT}

Propagation by cuttings is an effective method for ex-situ conservation of plants. In the present study, propagation of Ginkgo biloba L. was conducted using hardwood and semi hard wood cuttings. The cuttings from basal part of the tree were selected for the experiment and planted during rainy (i.e. July) and summer season (i.e. April) at Central Department of Botany, T.U. Cuttings beds were prepared using 3:1 sand and soil. Different concentration of auxins such as IAA, NAA and IBA were found effective in inducing rooting. During July, the stem cuttings treated with 1000 ppm IAA for 30 minutes induced highest percentage $(90 \%)$ and statistically significant $(P<0.05)$ rooting while those treated with same concentration and time induced only $40 \%$ rooting during April. Like wise other auxins NAA and IBA induced more rooting during July and less rooting during April. Cuttings planted as control, during July showed $10 \%$ rooting while during April did not show any rooting. Among all the auxins studied, IAA hormone and rainy season was found to be the most effective for rooting of $G$. biloba cuttings. From the anatomical study it was revealed that vascular cambium, secondary phloem, cortical cells and pericycle cells took part on rooting. Successfully rooted cuttings were then transferred to the natural soil condition.

Key Words: auxins, rooting, indole-3 acetic acid, indole-3 butyric acid, napthlene acetic acid

\section{INTRODUCTION}

Plants have their vital role in maintaining environment and their own value for medicinal, fibre, wood and their products are used in the huge amount. So it is necessary to propagate and conservation of germ plasm. Due to some biological constraints like long and short dormancy period and low viability of some seeds, the propagation of plants and conservation of germ plasm through seeds is not always successful. Such plants can be obtained genetically identical clones by cuttings which can support to conserve germplasm.

Propagation by cuttings is widely used, popular, inexpensive, rapid, simple and does not require sophisticated apparatus (Hartmann and Dale 1972, Nanda and Kochhar 1995). The four main types of stem cutting, herbaceous, soft wood, semi-hardwood, and hardwood, are commonly used (Dirr and Heuser 1987). In the beginnings of the rooting, callus is formed at the cuttings and then after fibrous (primary) root primordial, and tap (secondary) roots are developed (Hartmann and Dale 1972, Nanda and Kochhar 1995).

Rooting of cutting or in-vivo rooting is influenced by a number of external factors (light, temperature, humidity, aeration, season etc.), and internal (tissue characteristics of mother plants, nutrition root promoters, root inhibitor, presence of leaves, age of plant, crown where cuttings taken etc.) (Meson et al. 1997, Xie and Lin 1997). The presence of parenchymatous tissue facilitates the emergence of roots, while the presence of sclerenchymatous and fibrous tissue 
inhibits the roots formation (Hartmann and Dale 1972, Nanda and Kochhar 1995). Seasons greatly influence the adventitious root formation of cuttings (Palanisamy and Kumar 1997, Ono et al. 1997).

Ginkgo biloba L. is seed bearing, dioecious plant, native to China and Japan and exotic plant in Nepal. It is found in an altitude of about $1300 \mathrm{~m}$ in central Nepal. It is oldest living seed bearing plant (Arnold 1947), and is considered as living fossil due to the presence of primitive characters. It was originated in the Triassic period of the Mesozoic era and gradually thinned out during the cretaceous period of Cenozoic era. The name 'Ginkgo' was first proposed by Kaempfer (1690), an European botanist, and the same name was adopted by Linnaeus (1771) due to its fan shaped blobbed leaves. It is commonly called maiden-hair tree in Europe (Sporne 1965) because its new leaves resemble very much like those of Adiantum (called maiden hair fern). The extract of Ginkgo biloba is used for the treatment of various diseases and disorders disease like, psychiatric, ulcer, allergy, cardiovascular, pain, ophthalmic disease, skin disease, immunological disorders, digestive and endocrine (Davydov and Stirling 2001). It is also called bio-indicator because it might be applied in urban air quality assessment for detecting the existing effect of air pollutants and micro environmental stress in an urban ecosystem. Ginkgo biloba seeds have long dormancy period, so less number of seeds formation as well as takes long time for germination of seeds. Rooting of cutting is one of the best promising methods for propagation of that plant which is an effective method for the support of ex-situ conservation. Globally IUCN categorized Ginkgo biloba highly threatened and rare (R) category. The main aim of this study is to study the influence of seasons and assess the hormone and right environmental condition for rooting of stem cuttings of Ginkgo biloba.

\section{MATERIALS AND METHODS}

Branches of Ginkgo biloba were taken at morning from the basal part of the plant in April and July 2006 and placed on water. From these branches $12-15 \mathrm{~cm}$ length cuttings were prepared. For beds preparation, $26.5 \mathrm{~b} \times 21 \mathrm{~h}$ sized clay pots were filled with few pebbles at the bottom for good aeration and the rest portion was filled with sand and soil 3:1. Debris of plants (leaves and pieces of twigs) was avoided during bed preparation to keep safe from fungus. Cuttings were treated with different concentration of IAA, IBA and NAA for 30 minutes. Beds were pierced with piece of stick or pencil. Treated cuttings were planted one on each hole in a slanting $\left(45^{\circ}\right)$ position after treatment. A set of cuttings were planted under control and placed on colourless plastic house

For the aeration inside the plastic house, different sizes of holes on plastic were made. The planted pots were watered every day till the final observation. Weeds growing around the cuttings were uprooted. After three months of plantation, the cuttings were taken out from the beds and dipped into water and measured the length, average length of roots and also counted the number of roots on each cuttings.

After 40 days of plantation some cuttings were taken for anatomical study. Whitish brown callus were observed at the base of cuttings, later from that callus roots developed. Thin sections at the region of rooting were made.

Statistical analysis was carried out by SPSS version 12. After three months of plantation 
period, cuttings were taken out from the beds for observation. After the completion of the study, the newly developed rooted stem cuttings were transferred to the pots placed on shade and watered time to time for their stabilization. Finally, successfully rooted cuttings were then transferred to the natural soil condition.

\section{RESULTS AND DISCUSSION}

Seasons greatly influenced the rooting of Ginkgo biloba cuttings. The cuttings treated with different concentration of different hormones planted at July (Rainy season) showed more roots, higher rooting percentage and statistically significant $(P<0.05)$ in comparison to those cuttings planted at April (Summer season) which is similar to the work of Dabadi (1975) and Ulcer et al., (2004). The cuttings under control at rainy season (July) showed $10 \%$ rooting while the cutting at summer season (April) did not show any rooting (Table 1-3).

Table 1. Effect of IBA on roots formation on futtings under varying concentrations on constant time of treatment at rainy and summer seasons.

\begin{tabular}{|c|c|c|c|c|c|c|c|c|c|c|c|c|c|}
\hline \multirow[t]{2}{*}{$\begin{array}{l}\mathrm{S} \\
\mathrm{N}\end{array}$} & \multirow{2}{*}{$\begin{array}{l}\text { Con- } \\
\text { centra- } \\
\text { tion } \\
\text { of IBA } \\
(\mathrm{ppm})\end{array}$} & \multicolumn{2}{|c|}{$\begin{array}{l}\text { Number of } \\
\text { rooted } \\
\text { cuttings }\end{array}$} & \multicolumn{2}{|c|}{$\begin{array}{c}\text { Callus forma- } \\
\text { tion }\end{array}$} & \multicolumn{2}{|c|}{$\begin{array}{c}\text { Successfully } \\
\text { rooted cuttings } \\
\text { (\%) }\end{array}$} & \multicolumn{2}{|c|}{$\begin{array}{l}\text { Total number of } \\
\text { roots emerged }\end{array}$} & \multicolumn{2}{|c|}{$\begin{array}{l}\text { Number of } \\
\text { roots per cut- } \\
\text { tings }\end{array}$} & \multicolumn{2}{|c|}{$\begin{array}{l}\text { Average length } \\
\text { of roots }(\mathrm{cm})\end{array}$} \\
\hline & & Rainy & $\begin{array}{l}\text { Sum- } \\
\text { mer }\end{array}$ & Rainy & $\begin{array}{l}\text { Sum- } \\
\text { mer }\end{array}$ & Rainy & Summer & Rainy & Summer & Rainy & Summer & Rainy & Summer \\
\hline 1. & 250 & 3 & 2 & + & + & 30 & 20 & 17 & 4 & 5.66 & 2.0 & 2.21 & 1.37 \\
\hline 2. & 500 & 4 & 3 & + & + & 40 & 30 & 18 & 13 & 4.5 & 4.33 & 3.16 & 2.73 \\
\hline 3. & 750 & 8 & 2 & + & + & 80 & 20 & 87 & 11 & 10.87 & 5.55 & 1.91 & 2.62 \\
\hline 4. & 1000 & 4 & 1 & + & + & 40 & 10 & 40 & 6 & 10 & 6 & 1.97 & 1.86 \\
\hline 5. & Control & 1 & - & + & - & 10 & - & 9 & - & 9 & - & 1.5 & - \\
\hline
\end{tabular}


Table 2. Effect of NAA on roots formation on cuttings under varying concentration on constant time of treatments at rainy and summer seasons.

\begin{tabular}{|c|c|c|c|c|c|c|c|c|c|c|c|c|c|}
\hline \multirow[t]{2}{*}{$\begin{array}{l}\mathrm{S} \\
\mathrm{N}\end{array}$} & \multirow{2}{*}{$\begin{array}{c}\text { Con- } \\
\text { centra- } \\
\text { tion } \\
\text { of IBA } \\
\text { (ppm) }\end{array}$} & \multicolumn{2}{|c|}{$\begin{array}{l}\text { Number of } \\
\text { rooted } \\
\text { cuttings }\end{array}$} & \multicolumn{2}{|c|}{$\begin{array}{l}\text { Callus } \\
\text { formation }\end{array}$} & \multicolumn{2}{|c|}{$\begin{array}{c}\text { Successfully } \\
\text { rooted cuttings } \\
(\%)\end{array}$} & \multicolumn{2}{|c|}{$\begin{array}{l}\text { Total num- } \\
\text { ber of roots } \\
\text { emerged }\end{array}$} & \multicolumn{2}{|c|}{$\begin{array}{l}\text { Number of } \\
\text { roots per cut- } \\
\text { tings }\end{array}$} & \multicolumn{2}{|c|}{$\begin{array}{c}\text { Average } \\
\text { length of roots } \\
\text { (cm) }\end{array}$} \\
\hline & & Rainy & Summer & Rainy & Summer & Rainy & Summer & Rainy & Summer & Rainy & Summer & Rainy & Summer \\
\hline 1. & 250 & 1 & 4 & + & + & 10 & 40 & 2 & 32 & 2.0 & 8.0 & 2.0 & 2.06 \\
\hline 2. & 500 & 2 & 2 & + & + & 20 & 20 & 72 & 11 & 36.0 & 5.5 & 2.33 & 2.59 \\
\hline 3. & 750 & 2 & 1 & + & + & 20 & 10 & 7 & 3 & 3.5 & 3.0 & 1.64 & 2.59 \\
\hline 4. & 1000 & - & - & - & - & - & - & - & - & - & - & - & - \\
\hline 5. & Control & 1 & - & + & - & 10 & - & 9 & - & 9 & - & 1.5 & - \\
\hline
\end{tabular}

Table 3. Effect of IAA on roots formation on cuttings under varying concentration on constant time of treatment at rainy and summer seasons.

\begin{tabular}{|c|c|c|c|c|c|c|c|c|c|c|c|c|c|}
\hline \multirow[t]{2}{*}{$\begin{array}{l}\mathrm{S} \\
\mathrm{N}\end{array}$} & \multirow{2}{*}{$\begin{array}{l}\text { Concen- } \\
\text { tration } \\
\text { of IBA } \\
\text { (ppm) }\end{array}$} & \multicolumn{2}{|c|}{$\begin{array}{l}\text { Number of } \\
\text { rooted } \\
\text { cuttings }\end{array}$} & \multicolumn{2}{|c|}{$\begin{array}{c}\text { Callus } \\
\text { formation }\end{array}$} & \multicolumn{2}{|c|}{$\begin{array}{c}\text { Successfully } \\
\text { rooted cuttings } \\
\text { (\%) }\end{array}$} & \multicolumn{2}{|c|}{$\begin{array}{c}\text { Total number of } \\
\text { roots emerged }\end{array}$} & \multicolumn{2}{|c|}{$\begin{array}{l}\text { Number of } \\
\text { roots per cut- } \\
\text { tings }\end{array}$} & \multicolumn{2}{|c|}{$\begin{array}{c}\text { Average } \\
\text { length of roots } \\
\text { (cm) }\end{array}$} \\
\hline & & Rainy & Summer & Rainy & Summer & Rainy & Summer & Rainy & Summer & Rainy & Summer & Rainy & Summer \\
\hline 1. & 250 & 4 & 2 & + & + & 40 & 20 & 25 & 11 & 6.25 & 5.5 & 1.54 & 2.07 \\
\hline 2. & 500 & 4 & 4 & + & + & 40 & 40 & 78 & 23 & 19.5 & 5.75 & 3.84 & 1.89 \\
\hline 3. & 750 & 8 & 3 & + & + & 80 & 30 & 108 & 17 & 13.5 & 5.66 & 3.0 & 2.65 \\
\hline 4. & 1000 & 9 & 3 & + & + & 90 & 30 & 140 & 16 & 15.55 & 5.33 & 4.66 & 2.47 \\
\hline 5. & Control & 1 & - & + & - & 10 & - & 9 & - & 9 & - & 1.5 & - \\
\hline
\end{tabular}

Cuttings of Ginkgo biloba showed selective response to different hormones concentration and have varied effects at the different levels of concentration and at various time of treatment on rooting. Soft, younger, vigorously growing, leafy and unwounded with budded cuttings rooted 
well in comparison to the older, slow growing, wounded, bud less and leaf less cuttings which are similar to the works of Nanda and Kochhar (1995) and Hartmann et al. (1981). Higher rooting percentage (90\%) was observed on the cuttings treated with IAA (1000 ppm) than the other hormones at rainy season (Table 1-3) which is similar to the works of Stefancic et al. (2006), Nautiyal et al. (1992), Pant (1998), Shamet and Dhimann (1991).

On the anatomical study of rooted cuttings vascular cambium, adjacent cells of secondary phloem at cortical region and pericycle cells took part in callus formation which is analogous to the work of Hartmann and Dale (1972), from that callus root promordia developed and finally the vascular strands of roots connected with the main strands.

From this experiment, it can be concluded that rainy season is better for rooting in stem cuttings of Ginkgo biloba is determined by many factors: seasons, temperature, presence or absence of leaves and buds on the cuttings, tissue system, watering and humidity, number of leaves present on cuttings and type of cuttings used i.e. hard wood, softwood and semi hard wood. Due to the long dormancy period, seed germination of Ginkgo biloba takes long time so in-vivo rooting is one of the best promising methods for propagation which is an effective method for the support of ex-situ conservation.

\section{ACKNOWLEDGEMENTS}

The authors are thankful to Central Department of Botany and Biotechnology Unit, Tribhuvan University for providing laboratory facilities to conduct this research work,

\section{REFERENCES}

Arnold, C.A.,1948. Classification of gymnosperms from the point of view of paleobotany. Bot. Gaz., 110: 2-12.

Dabadi, N.,1976. Seasonal changes in the rooting behaviour of stem cuttings of Salix tetrasperma Roxb and Populus nigra Linn., in response to Indole-3 Butyric Acid, Naphthalene Acetic Acid and 2, 4-Dichloro Phenoxy Acetic Acid. Botany Instruction Committee, T.U.

Davydov, L. and A.L. Stirling, 2001. Stevens- Johnson syndrome with Ginkgo biloba L. Journal of Herbal Pharmacotherapy, 1(3):65-69.

Dirr, M.A.and C.W. Heuser,1987. The reference manual of woody plant propagation, from seed to tissue culture. Variety Press, Athens, Georgia.

Hartmann, H.T. and E.K. Dale,1972. Plant propagation, principles and prictices. Prentice-Hall Inc. Englewood Cliffs, NJ 07632, USA.

Hartmann, H.T., W.J. Folker and A.M. Kofranels,1981. Plant science: Growth, development and utilization of cultivated plants. Prentice-Hall Inc. Englewood Cliffs, NJ 07632, USA.

Kaempfer, E.,1690. Amoenitatum Exoticarum, 5:811-813.

Meson, F., A.C. Newton and R.R.B. Leakey,1997. Vegetative propagation of Cordia alliodora (Ruiz and Pavan) Oken. Forest Ecology and Management, 92(1-3):45-54.

Nanda, K.K.and U.K. Kochhar,1995. Vegetative propagation of plants. Kayani Publishers, New Delhi, India. 
Nautiyal, S., U. Singh and K. Gurumurti,1992. Rooting response of branch cuttings of teak (Tectona grandis) as influenced by growth hormones and position of the uttings on the crown. Indian Forester, 118(2):112-121.

Ono, E.O., J.D. Rodrigues and S.Z. Pinho,1997. Action of auxins on the rooting of stem cuttings of kiwi (Actinidia chinensis P. Cv Monty). Phyton Buenos Aires, 60(1-2):1-10.

Palanisamy, K. and P. Kumar,1997. Seasonal variation on adventitious rooting in branch cutting of Poagamina pinnate Pierre. Indian Forester, 123(3):236-239.

Pant, K.K.,1998. Propagation of Taxus baccata L. sub species wallichiana (Zucc) Pilger and Podocarpus nerifolius D. Don". A dissertation submitted for M.Sc., T.U.

Pincus G. and K.U. Thimam,1948. The hormone: Physiology, chemistry and applications. New york Academic Press.

Shamet, G.S. and R.C. Dhiman.,1991. Effects of auxins (IAA, IBA, NAA) on rooting behaviour of Grewia Optiva Burrett. Stem cuttings under intermittent mist. Indian Forester, 177(1):44- 47.

Sporne, K.R.,1965. The morphology of gymnosperms: The structure and evaluation of primitive seed-plants. Hutchimson Univ. Library, London.

Stefancic, M., F. Stampar and G. Oterc., 2006. Influence of IAA and IBA on roots development and quality of Prunus 'GiselAS' Leafy Cuttings, the dwarfing cherry rootstock. Hortscience, 40(7):252-255.

Ucler, A.O., S. Parlak and Z. Yucesan, 2004. Effect on IBA and cutting dates on the rooting ability of semi-hard wood kiwifruit cuttings. Turkish Journal of Agriculture and Forestry, 28(3):195-201. Xie, G.W. and W. Lin,1997. Vegetative propagation of Morimopetalum chinese Rehd. China. Journal of Plant Resources and Environment, 6(4):31-34.

\section{AUTHOR'S ADDRESS}

\section{Nabin Bhattarai ${ }^{1}$}

Nepal Mega College, Babarmahal, Kathmandu

(email: bhattarai_nab207@yahoo.com)

\section{Sanu Devi Joshi ${ }^{2}$}

Central Department of Botany, Tribhuvan University, Kirtipur, Kathmandu, Nepal 